Отримано: 3 жовтня 2018 р.

Прорецензовано: 5 жовтня 2018 р.

Прийнято до друку: 6 жовтня 2018 р.

e-mail: valerymykhaylenko@i.ua

DOI: $10.25264 / 2519-2558-2018-3(71)-15-18$
Mykhaylenko Valery. Old english 'hwæt' revisited: a cognitive approach. Наукові записки Національного університету «Острозька академія»: серія «Філологія». Острог : Видво НаУОА, 2018. Вип. 3(71), вересень. С. 15-18.

Valery Mykhaylenko

УДК811.111’367.628

doctor of Philology, professor, Institute of International Relations and Social Studies, MAUP, Kyiv

\title{
OLD ENGLISH ‘HW/ET’ REVISITED: A COGNITIVE APPROACH
}

The objective of our research is to study the interjection function of the OE unit hwcet in its functional paradigm and the context of actualization in the text structure of Beowulf. We consider that in the framework of various linguistic theories the authori differentiate between (a) morphological functions - pronominal, adjectival and adverbial; (b) communicative functions - attention-getting, connative, interrogative (Walkden, 2013), interpersonal and (c) discourse functions - complementizing, cohesive, pragmatic (Bergs, 2012) that brought to a functional mix which needs a corpus analysis based on the numerous Old English data retrieved from the texts of various genres. In Contemporary English what is used as determiner, pronoun, and exclamation marker: in questions that shows surprise or shock or a strong emotion about something. Besides, we must also note that in fact, OE manuscripts never show punctuation between hwcet and a following clause. And the type of phrase or clause associated with exclamations is called exclamative. Regular renderings of hwcet, in the initial position are rendered into Modern English by what-interrogatives ah! now; why 'lo;', 'hark;', 'behold;', 'attend.' (Brington, 1996). We consider that in the framework of various linguistic theories the authors differentiate between (a) morphological functions - pronominal, adjectival and adverbial; (b) communicative functions - attention-getting, connative, interrogative, interpersonal and (c) discourse functions - complementizing, cohesive and pragmatic.

Key words: interjection, etymology, semantics, pragmatics, function, text.

\section{Валерій Михайленко,}

доктор філології, професор, Інститут міжнародних відносин і соиіальних наук МАУП, Київ

\section{ДАВНЬОАНГЛІЙСЬКА ОДИНИЦЯ НШАТ: КОГНІТИВНИЙ ПІДХІД}

Метою нашого дослідження є вивчення давньоанглійської одиниці hwсt в ї̈ функиіональній парадигматиці у структурі текcmy Bеоwulf. У рамках різних мовних теорій автори вирізняють такі функції hwсеt: (а) морфологічні - займенникова, ад’єктивна та прислівникова; (б) комунікативні - привертання уваги, імперативна, питальна (Walkdеп, 2013), міжособистісна та (с) дискурсивні - когезивна, міжособистісна та прагматична (Bеrgs, 2012), щзо призводить до функціонального перетину, яке потребує корпусного аналізу для перевірки кожної функиії у різножанрових давньоанглійських текстах.

Ключові слова: вигук, етимологія, семантика, прагматика, функція, текст.

\section{Валерий Михайленко,}

доктор филологии, професор, Институт международных отношений и соииальных наук, МАУП, Киев

\section{ДРЕВНЕАНГЛИЙСКАЯ ЕДИНИЦА НWАТ: КОГНИТИВНЫЙ ПОДХОД}

Целью нашего исследования является изучение древнеанглийской единицы hwсt в её функциональной парадигматике в структуре текста Веошulf. В рамках различных языковых теорий различают такие функиї̈ hwсt: (a) морфологические функции местоименная, адъективная и адвербиальная; (б) коммуникативные - привлечения внимания, побудительная, вопросительная (Walkden 2013), межличностная и (c) дискурсивные - когезивная, межличностная и прагматическая (Вегgs, 2012), что приводит к функциональному пересечению, которое требующет корпусного анализа для проверки каждой функиии в разножанровых древнеанглийских текстах.

Ключевые слова: междометие, етимологія, семантика, прагматика, функція, текст.

Preamble. Interjections have neither been among the main research interests of modern grammarians nor of scholars of AngloSaxon studies. OE grammars and handbooks often do not even mention them. [13, p.168; 9, p.463]. In present day linguistics interjections have come into focus of research due to their formal simplicity, but semantic complexity in the discourse structure and become 'the subject of active debate' Cruz (2009) admits that the current relevance-theoretic approach to interjections, introduced by Tim Wharton [20, p.39-40], who reveals that they encode procedural information and contributed to the recovery of higher level explicatures [see also 13, p.390-393].The OE interpretation meets some difficulty for they are characteristic of oral discourse, wherein they are used in a number of functions. Consequently, linguists have to analyse their recorded variants in written monuments, where their colloquial nature is lost due to their descriptive relating. We believe that this is the cause of their being labeled quite subjectively as adjectives, adverbs, as complementizer of the object clause, or just pragmatic/ interrogative/exclamative markers. Interjections are also considered to be non-propositional units with modal senses (affective, epistemic, conative/deontic, etc ). Consequently, their presence or absence would not affect the truth-value of a proposition, besides, the punctuation symbol known as the exclamation point (1824) or exclamation mark (1926) was earliest called an exclamation note or note of exclamation (1650s); Shakespeare has note of admiration (1611). Another name for it was shriek-mark (1864). The mark itself is said to date to c. 1400 among writers in Italy and to represent the Latin io!, an exclamation of delight or triumph, written with the $-i$ - above the -o-

The objective of our research is to study the interjection function of the OE unit hwæt in its functional paradigm and the context of actualization in the text structure of Beowulf. Different editors introduce their own interpretation of the sentence syntactic structure, e.g.: C.W.M. Grein (2013) restructured the first 98 lines into turned into 19 complete sentences, 14 closed with periods, and 4 with exclamation points followed by capitals in the next words, cf.: Levin L.Schuckling (2017) turned the same 98 lines into 
31 complete sentences, Chamber's edition into 23 complete sentences (2009) and Fr. Klaeber's edition (1941; 1922) into 20. It is scarcely possible, says Emerson (1926), that all these systems of punctuation represent desirable divisions of the same matter and the author's intention in particular.

We must also note that in fact, OE manuscripts never show punctuation between hwcet and a following clause [15, p.525], and the same is true of Old Saxon: no punctuation mark is ever found between huat and a following clause in any of the manuscripts of the Heliand containing a relevant example (Cotton, Munich, Straubing).

Theoretical grounding: Historically interjections have been treated in two different ways: as part of language, or as non-words signifying feelings or states of mind [20, p. 173-175].Though interjections also have various other functions, e.g. as discourse markers, and conversely emotions can be expressed in various other ways. (1) Interjections have a meaning they express. (2) Phonologic and morphologic: Interjections are phonologically and morphologically irregular and have no fixed shape or structure; they are pronounced 'with an unformed voice or sound' or 'with an unclear (lit. concealed) voice/an unclear sound'. Eric Weiskott underlines that interjections compile a set of emotive qualitative judgments [21, p. 25-26; 13, p. 170].

In accordance with the grammatical tradition Ælfric also mentions the main characteristics of the interjections, some of which are still re-iterated in present day grammars. Translated into modern terminology these are: The emotions which Ælfric mentions, can be expressed by Latin interjections. The OE word hweet is well known (Blockley, 2001) within Anglo-Saxon studies as the first word of the epic poem Beowulf. In editions of Beowulf this hweet is often followed by a comma or an exclamation mark. It is commonly held that the word can be 'used as an adverb, or interjection: hwcet «why! what! ah!'» (Bosworth \& Toller, 1898) as well as in its normal sense, familiar from Modern English [18, p.465]. Eric G. Stanley points out that Ælfric's grammar of Latin and OE (edition Zupitza, 1880) did not include hwæt as an interjection, commenting that ' $F l f r i c$ 's omission is surprising seeing that this word when used to open a sentence appears to function often as an interjection' [28, p. 541]. Alfred Bammesberger (2006) follows Eric G. Stanley (2000) in suggesting that hwæt 'can function more or less as an adverb' [15, p. 5] and accordingly translates it as 'truly' [2, p. 2006]. Other translations include 'What ho!' (Earle 1892), 'Lo!' (Kemble 1937), 'Hear me!' (Raffel 1963), 'Yes,' (Donaldson 1966), 'Attend!' (Alexander 1973), 'Indeed' (Jack 1994), 'So.' (Heaney 1999) and 'Listen!' (Liuzza 2000). The OED gives that hwæt can be 'used to introduce or call attention to a statement' in older English, citing the above example among others. Bruce Mitchell and Fred Robinson go so far as to analyse this instance of hwcet as an extra-metrical 'call to attention', although this is far from universally accepted [10, p. 45; see also 15 , p. 555; 2, p. 7].

This use of hwat is found not only in early Old English verse but also in prose, as in the following examples from the writings of Ælfric and the Old English Bede: hwæt se soðlice onwriið his fæder scondlicnesse hw. he truly discovers his father's nakedness. (Bede, 1:16.70.15.657).

Corpus analysis. Most linguists include interjections into formal and systemic language descriptions. However, certain distinctive features of the formal and semantic structure of these words cause the collapse of some of the principal oppositions forming the basis of the majority of structural approaches to the language, i.e. synchrony and diachrony; statics and dynamics; langue, language and parole [16, p. 425-6].

Hans Sauer focused his research on two Old English texts, namely Ælfric's Grammar (ten Old English interjections), where there is a chapter on the word-class of interjections expressing, emotions, and the OE Soliloquies ( $\bar{E} a-\mathrm{oh} ; \bar{E}$ ala - lo, oh (also said when seeing someone - like an acknowledgement); Hpcet - what! La frequently used in combination with other words or interjections - see $\bar{e} a l \bar{a}$ above) - lo; $p \bar{a}$ - misery! woe! pel, pel - well, well), which how the use of interjections in a dialogue [13, p. 172-173]. The linguist distinguishes formally between primary and secondary interjections - morphologically simple and morphologically complex interjections and can also serve as attention getters, as greeting forms, as response forms, etc.

(a)The Old English hwcet originally was used in direct questions as an interrogative pronoun:

1. Hwcet sind Jás búton prymsetl heora Scyppendes «What are these but thrones of their Creator?» Homl. Th. i. 346, 11.

(b) In combination with the 2-nd person pronoun: hwæt +_ ú when the speaker shares knowledge with the addressee:

2. Hwat befealdest ðú folmum ðínum bróðor ðínne «Why hast thou felled thy brother with thy hands?» Cd. 48;

(c) The speaker uses hwæt + we to attract the addressee's attention:

3. Hwæt_wé nú gehýrap ah! now we learn, Cd. 45; Th. 57, 36; Gen. 939.

From a morphological and word-formational point of view in Aelfric's Grammar there are thus at least four groups: (1) morphologically simple primary interjections: la, hui(g); (2) morphologically simple secondary interjections: wa; (3) morphologically complex interjections, which can be subdivided into (a) combinations consisting of primary interjections: eala, haha / hehe, hilahi, wellawell, and (b) combinations consisting of secondary and primary interjections (afæstla, wala); (4) full and condensed phrases: wa is me; wamme [13, p. 171-172].

Bothworth and Toller define hwcet: (i) neut. of hwá, used as an adv. or interj. Why, what! ah! (ii) adj. Quick, active, vigorous, stout, bold, brave ; (iii) adv. or interjection. Add:I. in direct questions; (iv) adj. Add Huæt, huet, huaet licidus, lucidus. Brian A. Shaw writes that the hero of Beowulf made 15 speeches interrupted by interjections on the part of the author. The first seven occurred either before or directly after the battle with Grendel, the eighth speech introduces the continuation of evil in the person of Grendel's mother. The remaining seven speeches build up to the dragon fight and the outcome of that contest. [14, p. 86-87]. George Walkden says that hwæt, as well as being the nominative/accusative neuter singular of the interrogative pronoun, was able to perform an extra role in OE [18, p.469], as in the first line of Beowulf:

4. Hwæt we Gardena in geardagum• «hwat we Spear-Danes.(GEN) in year-days.

(DA) peodcyninga prym gefrunon nation-kings (GEN) power. (ACC) heard hu ða æpelingas ellen fremedon· how then/those. (NOM) princes.(NOM) valour performed [Beowulf, lines 1-3].

So far we have seen the traditional view of hwæt as an adverb or interjection (Bosworth \& Toller,1898) outside the clause and potentially extrametrical, possibly serving as a 'call to attention' (Mitchell \& Robinson 1998), suffers from a number of problems, many already noted by Grimm (1837) and Stanley (2000): (a) Hwcet must usually be analysed as being unstressed; (b) no punctuation between $h w c e t$ and the following clause is ever found; (c) a contemporary grammarian did not analyse hwcet as an interjection; (d) hwcet is not exclusively found in texts connected to primary orality, and does not always serve to initiate speech. Frederik Visser 
provides several examples of what he considers to be SV word order with initial interrogative hwcet [30, p. 1547], but as Bruce Mitchell points out, 'these can all be taken as non-dependent exclamations' [9, p. 680]. Paul Hopper (1977) suggests that the hwcetconstruction is quasi-formulaic and may therefore be likely to have the 'archaic' verb-final order, but does not go into any detail on this point. Likewise, Bruce Mitchell [9, p. 299-300, fn. 95] suggests that interjections like efne 'lo!/behold!' and hwoet may influence word order, but does not elaborate on this. More recently, within a generative framework, it has been observed that 'verb-final root clauses in OE prose undergo some influence of style in the word order after the interjection hwcet' [18, p. 472]. Current and past analyses of exclamatives (Bolinger, 1972; Rett, 2009) have generally proposed that a key component of the interpretation of exclamatives is that their content must involve something related to degree/scalarity. According to the semantic proposal of Jessica Rett the following two restrictions on the content of exclamatives: the degree restriction - an exclamative can only be used to express surprise that the degree property which is its content holds of a particular degree. and the evaluativity restriction - the content of the exclamative must additionally be evaluative: the degrees it makes reference to are restricted such that they must exceed a contextual standard [11, p. 147, 155].

Laurel J. Brinton (1996) analyses hwcet as a pragmatic marker, suggesting that its function is 'very similar to that of you know in Modern English.' Her reserch reveals a range of functions for hwcet: for instance, it may serve to introduce an insulting 'verbal assault' on the addressee; 'deference or solidarity'; 'respect to the status of information it introduces'; 'information to follow is common or familiar;' 'renewal of interest in that information' and/or focus attention on its importance;' but it may also precede new information [8, p.187-8]. She also suggests hwaet undergoes 'decategorialization' to a particle or interjection:

hwaet, hwy and where: interrogative in direct questions $\rightarrow$ complementizer in indirect questions $\rightarrow$ to pragmatic marker [9, p. 69-70].

We consider that in the framework of various linguistic theories the author differentiates between (a) morphological functions - pronominal, adjectival and adverbial; (b) communicative functions - attention-getting, connative, interrogative [see 18, p. 466] and interpersonal and (c) discourse functions - complementizing, cohesive and pragmatic [see 3, p. 202] that brought to a functional mix which needs a corpus analysis based on the numerous OE data. The type of interjections that Wierzbicka and Felix Ameka [212; see also1] have defined as emotive or expressive interjections lead the hearer to embed a proposition they accompany under a propositional-attitude description, enabling the hearer to comprehend the attitude expressed toward the proposition communicated. When an interjection appears as an independent utterance without an accompanying proposition, it provides (Cruz, 2009) the hearer with a vague idea of the speaker's feelings or emotions. Henri Weil writes that the initial position in the sentence is occupied by a unit which referent is familiar to the speaker to start his/her speech further on, i. e. in modern terminology he writes on the 'topic/ comment' [19, p. 21]. In the following illustrations hwat is recorded in the 'pre-sentence position as an independent sentence itself:

(a)HW FT (EXCLAMATIVE) = AN INDEPENDENT SENTENCE. In terms of constituent order, clauses introduced by $h w c e t$ in Old English and Old Saxon generally pattern statistically with subordinate clauses (including dependent questions and free relatives), rather than with root clauses as would be expected if hwoet were a free-standing interjection [18, p. 474]. Peter $\mathrm{S}$. Baker notes that a justly famous Old English hwcet usually begins many poems and Beowulf as well is sometimes interpreted (Baker, 2012) as a call for attention and sometimes as a signal what follows is in an elevated style: 4. (A). Hwcet! We Gardena ingeardagum,peodcyninga, prym gefrunon, hu ða cepelingas ellen fremedon. (B) «LO, praise of the prowess of people-kings of spear-armed Danes, in days long sped we have heard, and what honor the athelings won!» (C) Listen! We - of the Spear-Danes in the days of yore, of those clan-kings - heard of their glory how those nobles performed courageous deeds. MODEL of RENDERING: Old English hwaet $\rightarrow$ Modern English «lo» or «listen».

Matt Garley et al note that hwcet is a marker employed in the representation of spoken discourse. It occurs a total of five times in Beowulf, once as the first word of the poem - a part of the «narrator's» text. The other four instances all occur in the discourse of the characters, twice as the opening of their speech [13]: 5. (A)529-532. Béowulf mapelode bearn Ecgpéowes: «Hwot! pu worn fela, wine min Unferð, beore druncen ymb Brecan sprcece, sagdest from his siðe». (B) What a deal hast uttered, dear my Unferth drunken with beer, of Breca now. In this instance as well as in other four others hwæt occurs in the discourse of the characters. In two instances it is used as the opening of their speeches (1. 530, 1652). MODEL of RENDERING: Old Ebglish hwat $\rightarrow$ Modern English «what», «listen» or «hey» 1651-1654.

6. (A) Beowulf mapelode, bearn Ecgpeowes: «Hwcet! we pe pas scelac, sunu Healfdenes, leod Scyldinga, lustum brohton tires to tacne, pe pu her to locast». (B) BEOWULF spake, bairn of Ecgtheow: «Lo, now, this sea-booty, son of Healfdene Lord of Scyldings, we've lustily brought thee, sign of glory; thou seest it here». (C) Beowulf spoke, the son of Edgetheow: 'Listen, we you these seaspoils, son of Half-Dane, lord of the Scyldings, gladly brought as token of glory, which you look at here». MODEL of RENDERING: Old Ebglish hwaet $\rightarrow$ Modern English «lo (now)» or «listen».

(b) HW ET (EXCLAMATIVE) = AS A PART OF A CLAUSE: There is a paradox in syntax: an interjection as an initial part of the sentence is not considered to be a part of this sentence. J. Grimm notes that it always stands at the beginning of a clause, and that it often serves to introduce speech, or even a whole poem as in the case of Beowulf. His conclusion is that it is 'purely an exclamation, albeit in a very moderate sense (Grimm, 1837). Brinton (1996) analyses hwcet as a pragmatic marker, suggesting that its function is 'very similar to that of «you know» in Modern English:

7. (A) 1774-1778. Hwat, me pees on eple edwenden cwom, gyrn aefter gomene, seopðan Grendel wearð, ealdgewinna, ingenga min; ic pare socne singales waeg modceare micle. (C) «Listen, to me in the homeland for that a reversal came, sorrow after joy, since Grendel became an old contender, invader of mine,»...

\section{MODEL of RENDERING: Old Ebglish hwat $\rightarrow$ Modern English «lo» or «listen».}

8. (A)2246-2249. féa worda cwce:: "Heald pu nu, hruse, nu hceleðne moston, eorla cehte! Hwcet, hyt cer on ðe gode begeaton. (B) «some words he spoke: «Now hold thou, earth, since heroes may not, what earls have owned! Lo, erst from thee brave men brought it!» MODEL of RENDERING:Old English hwaet $\rightarrow$ Modern English «lo» or «listen».

(c) HWFT (INRERROGATIVE) +VERB: Slade Garley \& Terkourafi (2010) also discuss hwcet (Garley, 2009) in relation to Beowulf and their article provides a useful summary of the received wisdom regarding the word. They take it to be a discoursestructuring formula, 'a marker employed in the representation of spoken discourse' [9]. The interrogative function of hwaet in inde- 
pendent questions exists in Early Old English: 9. A. 237-240. «Hwcet syndon ge searohoebbendra, byrnum werede, pe pus brontne ceol ofer lagustrcete lcedan cwomon, hider ofer holmas?» (B) Who are ye, then, ye armed men, mailed folk, that yon mighty vessel. «MODEL of RENDERING:Old Ebglish hwat $\rightarrow$ Modern English «what/' or «who».

(d) HWAT (COMPLEMENTIZER) + CLAUSE: Brinton also discusses a possible grammaticalization of $h w c e t$ from its origins as an argumental interrogative pronoun [8, p.199-206]. The author follows the functional view suggested by Elizabeth Traugott (1982) on hwæt, and adds that, in broad terms hwaet, hwy and where seem to have a similar formula of developing: from interrogative in direct questions to complementizer in indirect questions and then to pragmatic marker [9, p. 69-70]: 10. (A)171-174. Monig oft gescet rice to rune; rad eahtedon hwcet swiðferhðum selest ware wiðfcergryrum to gefremmanne (B) «Many nobles sat assembled, and searched out counsel how it were best for bold-hearted men against harassing terror to try their hand». MODEL of RENDERING:Old Ebglish $\boldsymbol{h}$ waet $\rightarrow$ Modern English «what» or «how». There is an opinion that of the 14 uses of $h w c e t$ in Beowulf, six are very discourse marked. No doubt, the longer context the more discourse-charged the hwat units will be, for instance, in the following three instances of hwcet occur in dialogue: 11. (A)530 «Hwoet! pu worn fela, wine min Unferð, beore druncen ymb Brecan sprcece, saegdest from his siðe...» (B)«Well, friend Unferth, you have had your say...» (Heaney).

We consider that in the framework of various linguistic authors differentiate between (a) morphological functions - pronominal, adjectival and adverbial; (b) communicative functions - attention-getting, connative, interrogative [see 18, p. 466] and interpersonal and (c) discourse functions - complementizing, cohesive and pragmatic [see 5, p.202] that brought to a functional mix which needs a corpus analysis based on the numerous Old English data. Regular renderings of $h w c e t$, in the initial position are represented in Modern English by what-interrogative ah! now; why 'lo;', 'hark;', 'behold;', 'attend.' [8, p. 188].

The findings and perspectives. The traditional view of Old English hweet as an interjection meaning simply 'lo!' or 'listen!', as proposed by Grimm (1837) and assumed 'by all Anglo-Saxonists' [15, p. 541], is arguable [18, p. 484]. This is because (a) hwæt must usually be analysed as unstressed where it occurs in metrical texts, (b) no punctuation between it and the following word and no punctuation is registered in the original manuscript. Wh- exclamatives do not include any asserted meaning, instead, they contain a backgrounded descriptive content and an implicated meaning that is identified as an attitude towards a degree, none of which have assertoric power (Orchard, 2003).

Our end-goal is to define the ways of hwcet further grammarticalization in English.There are two main 'engines' of the language evolution - grammaticalization and lexicalization.

\section{References:}

1. Ameka Felix. Interjections : The universal yet neglected part of speech. Journal of Pragmatics. 1992. Vol.18. P. 101-118.

2. Bammesberger Alfred. The syntactic analysis of the opening verses in Beowulf.

3. Bergs Alexander, Brinton Laurel J. (eds.). English historical linguistics. Vol.1. Berlin/Boston: Walter de Gruyter, 2012.1196 p.

4. Brinton Laurel J. Pragmatic markers in English: Grammaticalization and discourse functions. Berlin: Mouton de Gruyter, 1966. 412 p.

5. Brinton Laurel J. The Evolution of pragmatic markers in English: Pathways of change. Cambridge: Cambridge University Press, 2017. $344 \mathrm{p}$.

6. Hiltunen Risto. «Eala, geferan, gode wyrhtan:» On Interjections / Ed. John Walmsley. Inside Old English: Essays in Honour of Bruce Mitchell. John Wiley \& Sons, 2016. P. 91-112.

7. Miró Elena Castroviejo. Deconstructing exclamations. Catalan Journal of Linguistics. 2008. Vol.7. P. 49-90.

8. Mitchell, Bruce. The Dangers of Disguise: Old English Texts in Modern Punctuation. RES. 1980. Vol. 31. P. $385-413$.

9. Mitchell Bruce. Old English syntax. 2 vols. Oxford: Clarendon, 1985.

10. Mitchell Bruce, Robinson Fred (eds.). Beowulf: An Edition with relevant shorter texts. Oxford: Blackwell, 1998. 332 p.

11. Rett Jessica. A degree account of exclamatives. / Ed. Tova Friedman \& Satoshi Ito. Proceedings of SALT XVIII. Ithaca, NY: Cornell University, 2009. P.601-618

12. Sauer Hans. Interjection, emotion, grammar, and literature. / Ed. M. Amano, M. Ogura. Ohkado. Historical Englishes in Varieties of Texts and Contexts: The Global COE Program. International conference, 2007. Frankfurt am Main: Lang, 2007. P. 387-403.

13. Sauer Hans. How the Anglo-Saxons expressed their emotions with the help of interjections. Brno studies in English. 2009. Vol.35. Issue 2. P. 67183.

14. Shaw Brian A. The Speeches in «Beowulf»: A Structural Study. The Chaucer Review. 1978. Vol. 13, No.1. P. 86-92.

15. Stanley Eric Gerald. 'Hwæt'. / Ed. J.Roberts, and J. Nelson. Essays on Anglo-Saxon and related themes in memory of Lynne Grundy. London: King's College Centre for Late Antique \& Medieval Studies. 2000. P. 525-556.

16. Velmezova Ekaternia. Interjections: An insurmountable problem of structural linguistics? The case of early Soviet structuralism. /

Ed. Gerda Hassler. Studies in the History of the Language Sciences. 2011. Vol. 115. P. 425-434

17. Visser Frederik Theodoor. An Historical syntax of the English language. Vol. 1-3. Leiden: Brill, 1969 (1978). 2470 p.

18. Walkden George. The status of hwæt in Old English. English Language and Linguistics. 2013. Vol. 17. Issue 3. P. 465-488.

19. Weil Henri. De l'ordre des mots dans les langues anciennes comparees aux langues moderns. Paris: Joubert, Libraire-Éditeur, 1879

(1844). $103 \mathrm{p}$

20. Wharton Tim. Interjections, language, and the «showing/saying» continuum. Pragmatics and Cognition. 2003. Vol.11 (1). P.173-215.

21. Weiskott Eric. Making Beowulf scream: Exclamation and the punctuation of Old English poetry. The Journal of English and Germanic Philology. 2012. Vol. 111. No.1. P. 25-41.

22. Wierzbicka Anna. Cross-cultural Pragmatics: The Semantics of Human Interaction. Berlin / New York: Walter de Gruyter, 2003. $502 \mathrm{p}$. 